\title{
Pengembangan Vlog (Video Blog) Channel Youtube Berbasis STEM Pada Materi Laju Reaksi Kelas XI SMA/MA Indah Cahyani', Maya Sari ${ }^{2 *}$
}

\author{
Jurusan Tadris Kimia Fakultas Tarbiyah dan IImu Keguruan IAIN Batusangkar \\ `Email: mayasari@iainbatusangkar.ac.id
}

\begin{abstract}
Abstrak
Penggunaan media pembelajaran menjadi salah satu inovasi bagi siswa dalam memahami setiap materi pelajaran. Dalam proses pembelajaran, guru mesti memilih media pembelajaran yang sesuai dan efisien untuk mencapai tujuan pendidikan. Berkembangnya teknologi informasi mempengaruhi dunia pendidikan, dari pendidikan tatap muka konvensional ke arah pendidikan yang lebih terbuka. Perkembangan zaman yang semakin modern membuat individu bergantung pada teknologi, terutama smart phone. Dalam proses pembelajaran guru masih terbatas dalam pengembangan media, yang terlihat pada minimnya penggunaan media pembelajaran yang berbasis teknologi. Penelitian ini bertujuan untuk mengembangkan vlog (video blog) channel youtube sebagai alternatif pembelajaran kimia berbasis STEM. Jenis penelitian yang digunakan adalah penelitian dan pengembangan (Research and Development) dengan model rancangan 4D. Penelitian ini terdiri dari empat tahap yaitu: pendefenisisan (define), perancangan (design), tahap pengembangan (development) dan tahap penyebaran (disseminate). Namun pada penelitian ini hanya sampai pada tahap pengembangan (development) dikarenakan keterbatasan waktu dan biaya. Kelayakan produk dilakukan dengan melakukan validasi pada ahli media dan ahli materi. Kemudian, peneliti melakukan uji praktikalitas terbatas terhadap produk dengan menggunakan 10 orang siswa. Berdasarkan hasil validasi produk, diperoleh persentase $80 \%$ dengan kriteria valid, dan persentase praktikalitas vlog berbasis STEM yang dilihat dari angket respon siswa sebesar $96,13 \%$, sedangkan dari angket respon guru diperoleh persentase $90 \%$.
\end{abstract}

Kata kunci : Vlog, STEM dan Laju reaksi

\begin{abstract}
The use of learning media is one of the innovations for students in understanding every subject matter. In the learning process, teachers must choose appropriate and efficient learning media to achieve educational goals. The development of information technology affects the world of education, from conventional face-to-face education to a more open education. The development of an increasingly modern era makes individuals depend on technology, especially smart phones. In the learning process, teachers are still limited in media development, which can be seen in the minimal use of technologybased learning media. This study aims to develop a YouTube channel vlog (video blog) as an alternative to STEM-based chemistry learning. The type of research used is research and development (Research and Development) with a 4D design model. This research consists of four stages, namely: define, design, development stage and disseminate stage. However, this research only reached the development stage due to time and cost limitations. The development of an increasingly modern era makes individuals depend on technology, especially smart phones. In the learning process, teachers are still limited in media development, which can be seen in the minimal use of technology-based learning media. This study aims to develop a YouTube channel vlog (video blog) as an alternative to STEM-based chemistry learning. The type of research used is research and development (Research and Development) with a $4 D$ design model. This research consists of four stages, namely: define, design, development stage and disseminate stage. However, this research only reached the development stage due to time and cost limitations.
\end{abstract}

Keywords : Vlog, STEM and Reaction rate 


\section{Pendahuluan}

Berbagai upaya dapat dilakukan untuk membentuk generasi bangsa yang siap menghadapi masalah-masalah globalisasi apalagi di abad 21, dimana pada abad ini menitik beratkan pada aspek pendidikan. Menurut Asyhari (dalam Suratun tahun 2018) Pendidikan adalah bagian yang terpenting dalam kehidupan. Pendidikan yang baik adalah pendidikan yang mampu menciptakan siswa yang dapat memecahkan permasalahan di dunia nyata dengan mengimplementasikan ilmu yang di dapat dalam kehidupan sehari-hari. Dengan pendidikan akan tercipta sumber daya manusia yang mampu membawa perubahan diri sendiri, masyarakat maupun bangsa di abad 21 .

Berkembangnya teknologi informasi mempengaruhi dunia pendidikan, dari pendidikan tatap muka yang konvensional ke arah pendidikan yang lebih terbuka. Perkembangan zaman yang semakin modern dan serba canggih membuat individu bergantung pada teknologi, terutama smart phone. Dimana alat ini sering digunakan oleh banyak kalangan, mulai kalangan dewasa hingga anak-anak. Yang bertujuan untuk mengakses banyak hal, seperti bermain game online, untuk pesan singkat whatsapp, line dan masih banyak aplikasi yang dapat membantu aktifitas manusia. Salah satu aplikasi yang sedang diminati oleh anak-anak saat ini adalah Youtube. Dalam hal ini peneliti mengembangkan media pembelajaran vlog (video blog) channel youtube. Dimana Vlog dapat dikatakan sebagai media yang berbasis audio visual, karena hampir mirip dengan video yang lainnya, namun mempunyai tema tertentu dengan objek tertentu serta dikemas dalam gambar yang menarik yang di unggah di youtube, yang dapat di tonton secara online ataupun offline.

Dalam pengembangannya, peneliti menggunakan pendekatan STEM (Science, Technology, Engineering and Mathematics). Pendekatan STEM adalah pendekatan yang mengutamakan integrasi (science, technology, engineering dan mathematics) secara multi dan transdisiplin memberikan ruang bagi pengembangan pemikiran kritis, kreativitas, inovasi, dan kemampuan siswa dalam memecahkan masalah (Triastuti, 2019).

Hasil survei yang dilakukan di MAN 2 Kota Payakumbuh diperolah keterangan bahwa media yang digunakan dalam proses pembelajaran masih sangat terbatas seperti buku paket, buku LKS dan juga media power point yang mana penggunaan 
media ini dilakukan hanya pada materi tertentu saja. Tidak hanya itu proses pembelajaran masih konvensional dan proses pembelajaran bersifat satu arah (Teacher Centered). Upaya untuk menyelesaikan permasalahan ini salah satunya penggunaan model dan media yang efektif. Guru sebagai fasilitator harus terampil dalam memilih media pembelajaran yang sesuai dan efisien untuk mencapai tujuan pendidikan. Media pembelajaran sangat diperlukan dalam menunjang tercapainya tujuan pembelajaran. Media pembelajaran adalah sebuah alat yang dapat digunakan untuk menyampaikan sebuah isi dari pembelajaran yang dapat merangsang perhatian dan minat siswa sehingga siswa mengerti dengan isi yang disampaikan (Suratun, Irwandani, \& Latifah, 2018). Penggunaan media pembelajaran menjadi salah satu inovasi bagi siswa dalam memahami setiap materi pelajaran sehingga mereka termotivasi untuk selalu mengikuti proses pembelajaran tanpa mengalami kejenuhan.

Penelitian ini merupakan suatu inovasi terbaru dalam pembelajaran kimia. Peneltian pengembangan media vlog berbasis STEM ini belum pernah dilakukan pada penelitian orang lain sebelumnya khususnya pada mata pelajaran kimia. Berdasarkan permasalahan tersebut, maka peneliti tertarik untuk melakukan penelitian pengembangan media vlog berbasis STEM, dengan tujuan vlog berbasis pendekatan STEM ini berfungsi sebagai alternatif untuk mempermudah siswa dalam proses pembelajaran.

\section{Metode}

Metodologi penelitian dalam penelitian ini menggunakan metode penelitian dan pengembangan (Research and Devolopment) menggunakan model pengembangan 4D. Model pengembangan 4-D terdiri atas 4 tahap pengembangan, yaitu define, design, develop dan disseminate (Sugiyono, 2013). Tahap define terdiri dari wawancara dengan guru bidang studi, tahap analisa media pembelajaran, analisis kebutuhan siswa dan analisis Kompetensi Inti dan Kompetensi Indikator. Penelitian hanya dilakukan sampai pada tahap develop saja. Adapun kriteria suatu produk dinyatakan valid dan praktis apabila memiliki persentase nilai yaitu $61-100 \%$. Berikut ini disajikan bagan dari tahapan model pengembangan 4-D: 


\section{Tahap Define}

1. Wawancara dengan guru

2. Analisis media pembelajaran

3. Analisis kebutuhan siswa

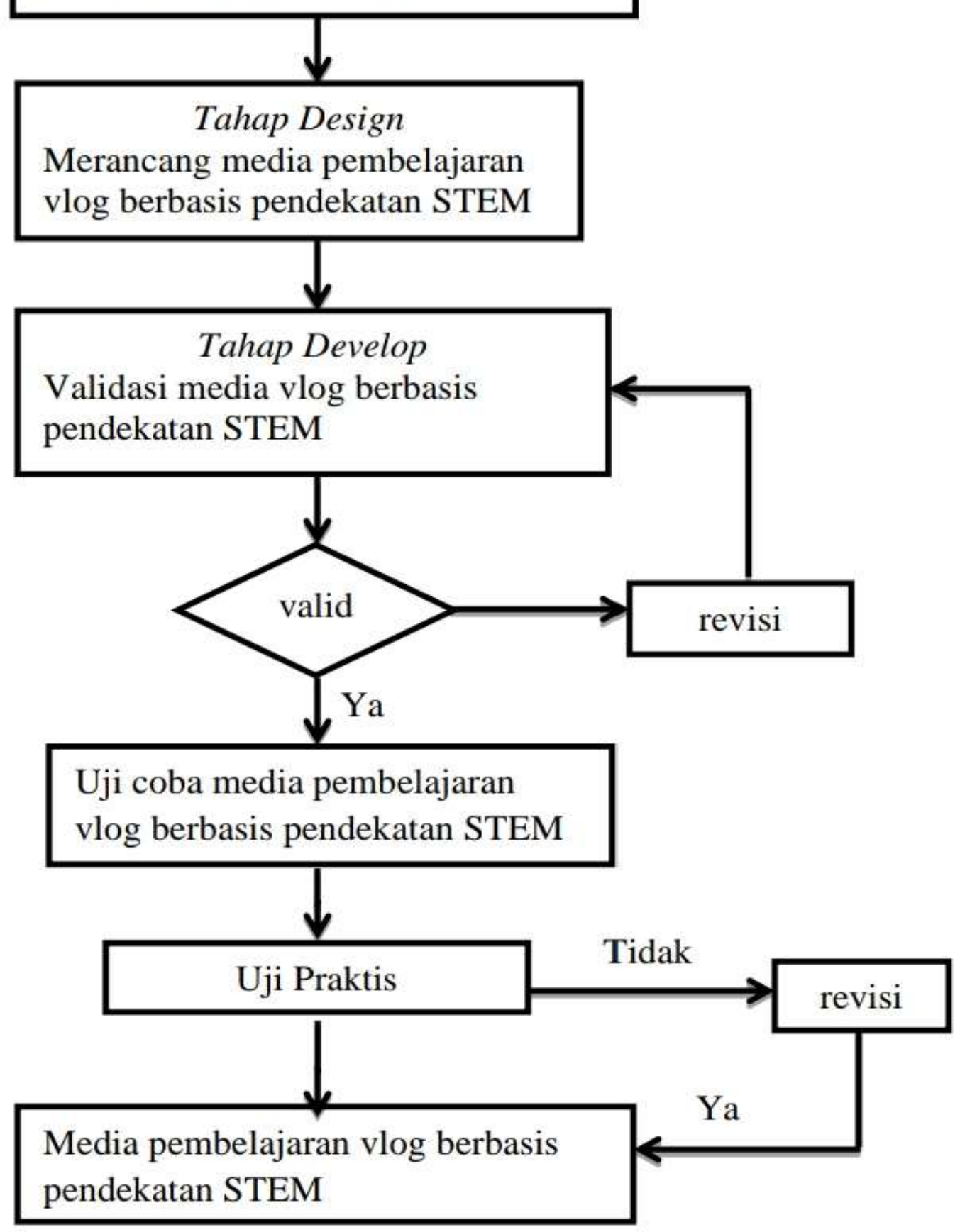

Gambar: Bagan Tahap Pengembangan Model 4-D 


\section{Hasil dan Pembahasan}

Pada tahap analisis ini didapat hasil bahwa perlu dikembangkan lagi media pembelajaran yang efektif dan efisien yang mendukung siswa dalam proses pembelajaran agar tujuan pembelajaran dapat tercapai. Selain itu, media pembelajaran dikembangkan terintegrasi STEM sebagai alternatif untuk membantu kegiatan belajar mengajar, baik yang dilakukan secara online atupun offline. Rancangan vlog (video blog) channel youtube dibuat dengan urutan sebagai berikut yaitu: 1) Membuat garis besar program media, 2) membuat flowchart, 3) membuat storyboard, 4) mengumpulkan bahan yang dibutuhkan, 5) pemograman dan 6) finishing.

Produk pengembangan vlog (video blog) channel youtube berbasis pendekatan STEM dapat dilihat pada tabel 3

Tabel 3 Storyboard dan Narasi

\begin{tabular}{|c|c|c|c|}
\hline $\begin{array}{l}\mathbf{N} \\
\mathbf{0}\end{array}$ & Keterangan & Visual & Audio \\
\hline 1. & Opening & $\begin{array}{l}\text { Loading } \\
\text { Teks: } \\
\text { Laju Reaksi } \\
\text { Animasi: } \\
\text { Logo IAIN Batusangkar } \\
\text { Logo HMJ Tadris Kimia } \\
\text { Pembukaan: } \\
\text { Assalamu'alaikum } \\
\text { warahmatullahi } \\
\text { wabarakatu }\end{array}$ & $\begin{array}{l}\text { Musik } \\
\text { Instrumen } \\
\text { Narator: } \\
\text { Selamat datang } \\
\text { dalam media } \\
\text { pembelajaran } \\
\text { kimia pada } \\
\text { materi laju } \\
\text { reaksi }\end{array}$ \\
\hline 2. & $\begin{array}{l}\text { Kompeten } \\
\text { si Dasar }\end{array}$ & $\begin{array}{l}\text { Judul: } \\
\text { Kompetensi dasar } \\
\text { Teks: } \\
\text { Memahami kinetika } \\
\text { reaksi kesetimbangan } \\
\text { kimia, dan faktor-faktor }\end{array}$ & $\begin{array}{l}\text { Musik } \\
\text { instrument }\end{array}$ \\
\hline
\end{tabular}




\begin{tabular}{|c|c|c|c|}
\hline & & $\begin{array}{l}\text { yang mempengaruhi laju } \\
\text { reaksi serta } \\
\text { penerapannya dalam } \\
\text { kehidupan sehari-hari }\end{array}$ & \\
\hline 3. & $\begin{array}{l}\text { Tujuan } \\
\text { Pembelaja } \\
\text { ran }\end{array}$ & 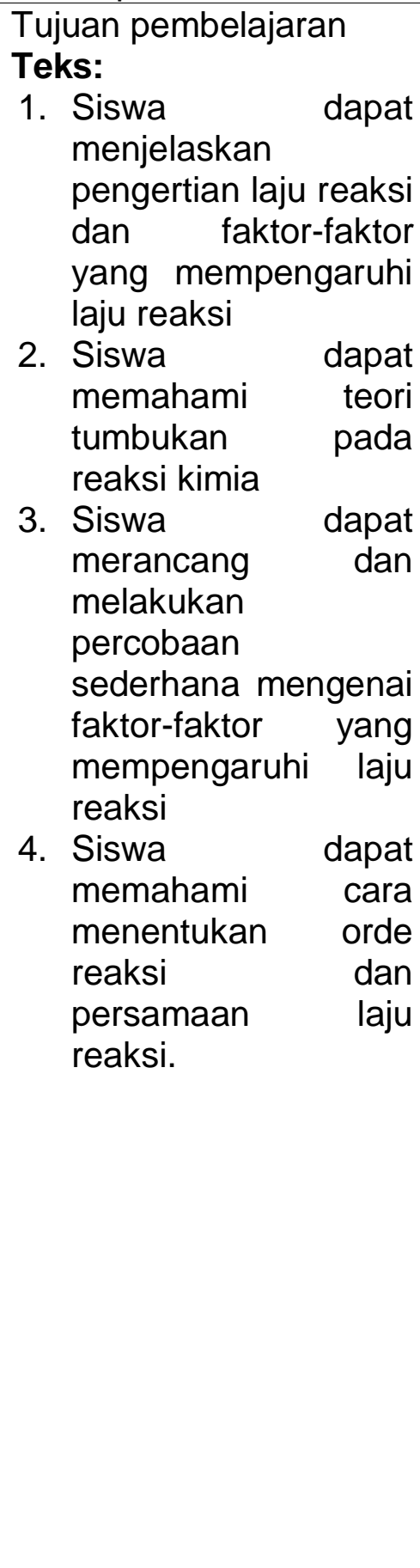 & $\begin{array}{l}\text { Narator: } \\
\text { Adapun tujuan } \\
\text { pembelajaran } \\
\text { yang harus kita } \\
\text { capai yaitu: } \\
\text { 1. Siswa dapat } \\
\text { menjelaskan } \\
\text { pengertian } \\
\text { laju reaksi } \\
\text { dan faktor- } \\
\text { faktor yang } \\
\text { mempengaru } \\
\text { hi laju reaksi } \\
\text { 2. Siswa dapat } \\
\text { memahami } \\
\text { teori } \\
\text { tumbukan } \\
\text { pada reaksi } \\
\text { kimia } \\
\text { Siswa dapat } \\
\text { merancang } \\
\text { dan } \\
\text { melakukan } \\
\text { percobaan } \\
\text { sederhana } \\
\text { mengenai } \\
\text { faktor-faktor } \\
\text { yang } \\
\text { mempengaru } \\
\text { hi laju reaksi } \\
\text { Siswa dapat } \\
\text { memahami } \\
\text { cara raju reaksi. } \\
\text { menentukan } \\
\text { orde reaksi } \\
\text { dan } \\
\text { persamaan } \\
\text { laju }\end{array}$ \\
\hline 4. & $\begin{array}{l}\text { Materi } \\
\text { Pokok }\end{array}$ & $\begin{array}{l}\text { Judul: } \\
\text { Materi pokok } \\
\text { Teks: } \\
\text { Laju Reaksi }\end{array}$ & Narator \\
\hline
\end{tabular}




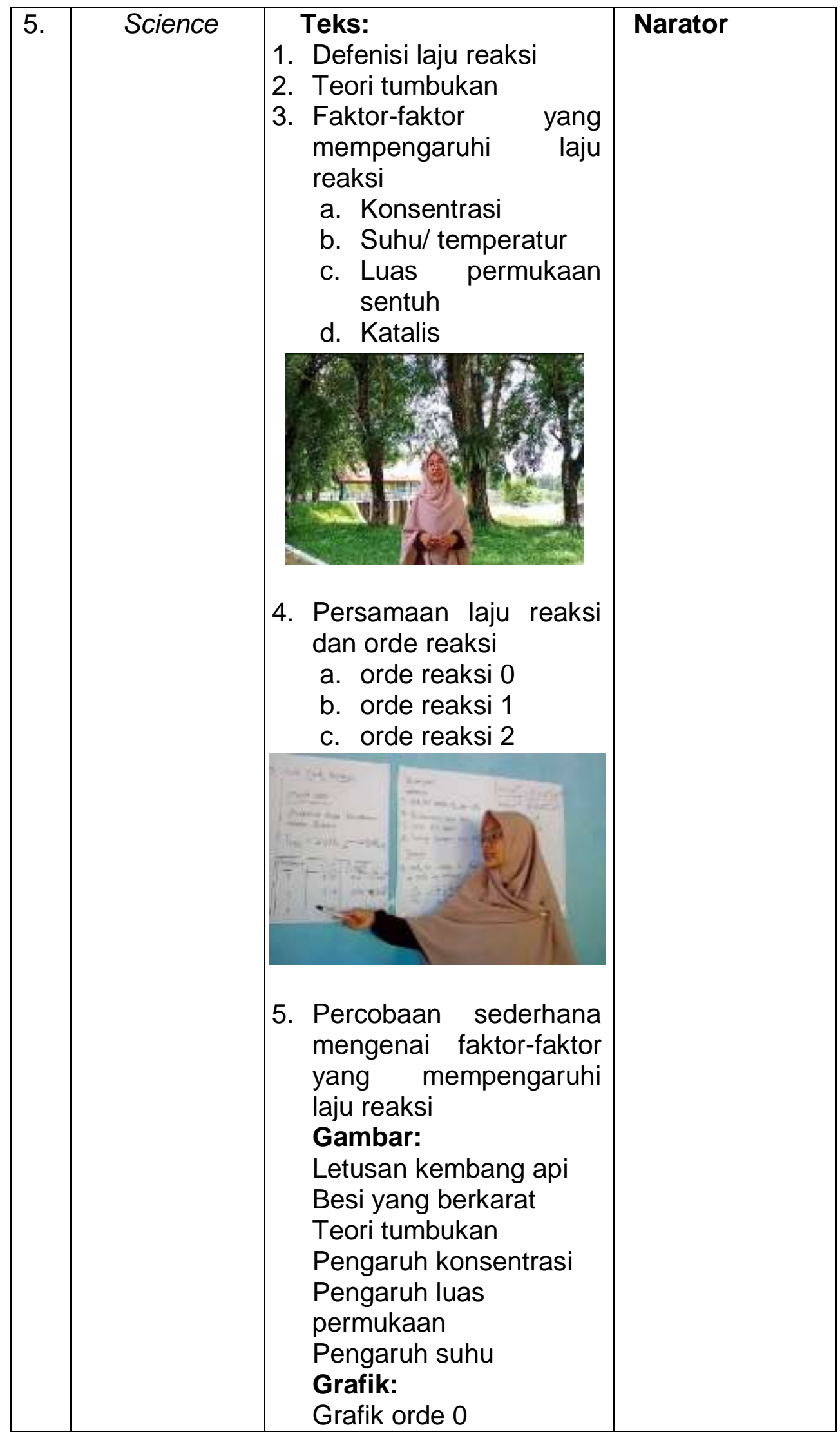




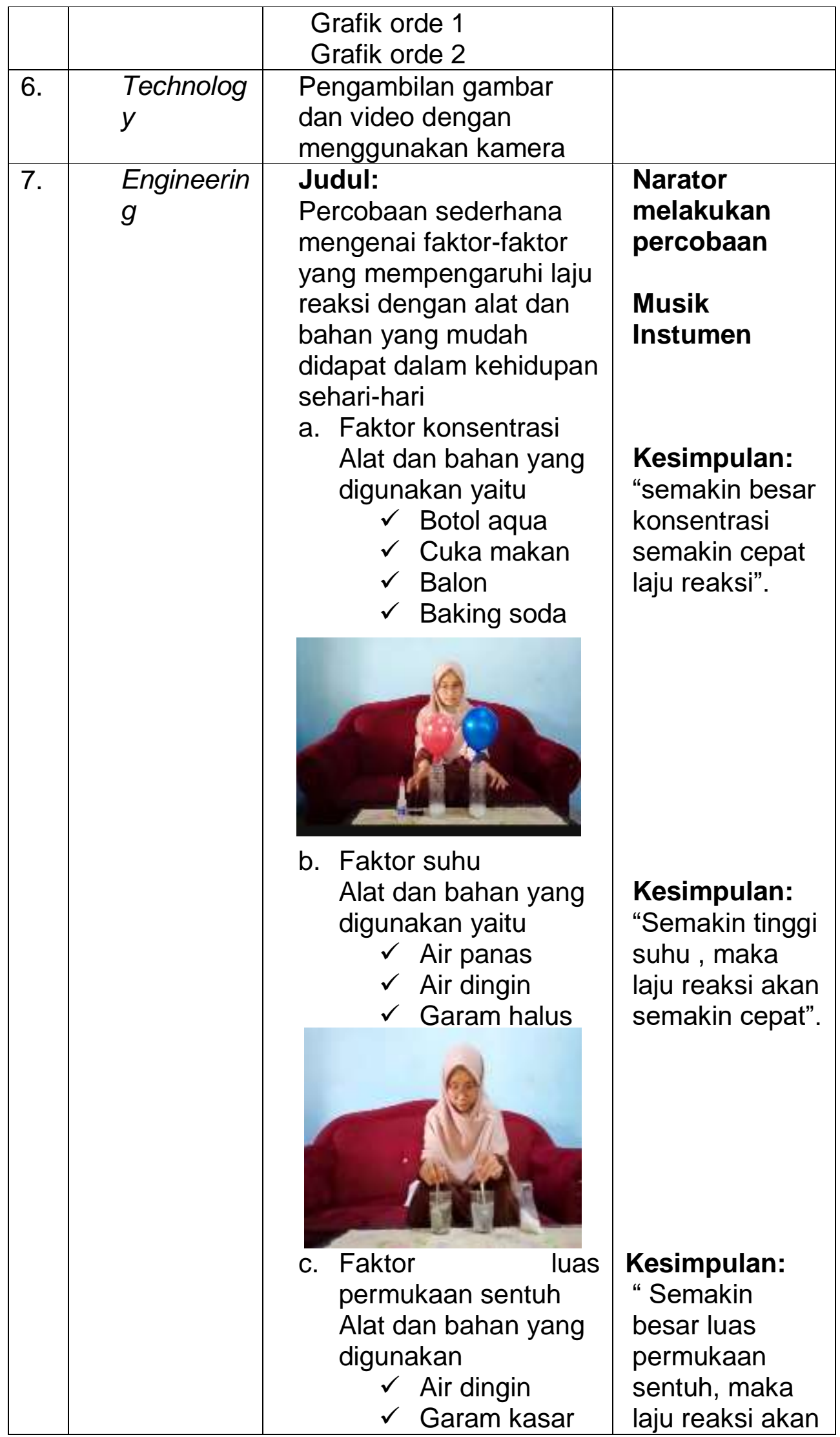




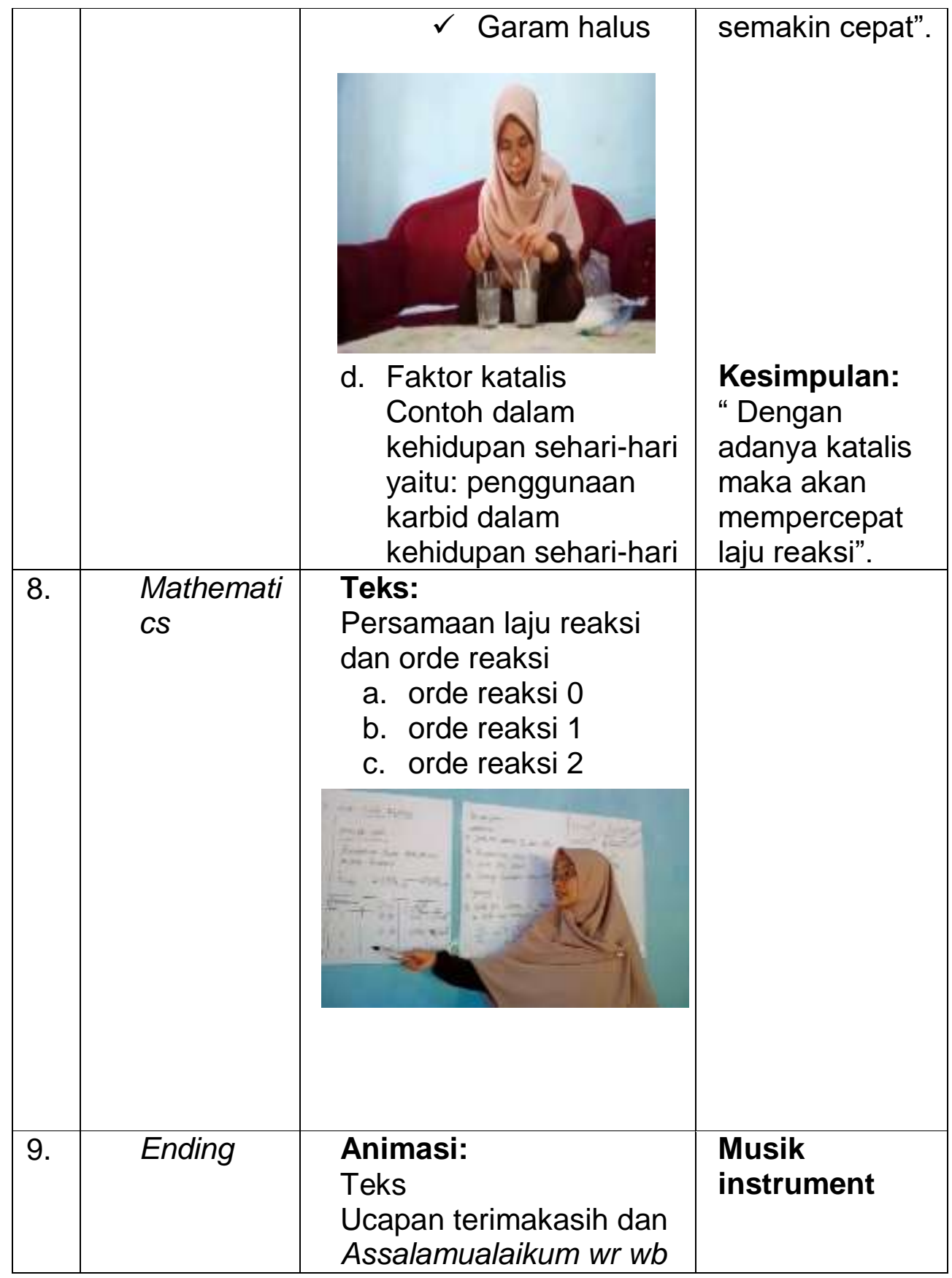

Hasil validasi terhadap media Vlog Berbasis STEM dapat dilihat pada tabel 4 berikut. Tabel 4 Hasil Analisis Validasi Vlog Berbasis STEM

\begin{tabular}{|c|c|c|c|c|c|c|c|c|}
\hline \multirow{2}{*}{$\begin{array}{l}\mathbf{N} \\
\mathbf{0}\end{array}$} & \multirow[b]{2}{*}{ Kriteria } & \multicolumn{3}{|c|}{ Validator } & \multirow{2}{*}{$\begin{array}{l}\text { Jum } \\
\text { lah }\end{array}$} & \multirow{2}{*}{$\begin{array}{c}\text { Skor } \\
\text { Mak } \\
\text { S }\end{array}$} & \multirow{2}{*}{$\%$} & \multirow{2}{*}{ Ket } \\
\hline & & 1 & 2 & 3 & & & & \\
\hline 1 & $\begin{array}{l}\text { Aspek Kualitas } \\
\text { Isi }\end{array}$ & 24 & 24 & 26 & 74 & 96 & 77 & Valid \\
\hline 2 & Aspek Kualitas & 24 & 21 & 26 & 71 & 84 & 85 & Sal \\
\hline
\end{tabular}


VOL 2 NO 2 BULAN 10 TAHUN 2020

DOI 10.25299/jrec.2020.vol2(2).5725

\begin{tabular}{|l|l|c|c|c|c|c|c|l|}
\hline & Instruksional & & & & & & & Valid \\
\hline 3 & $\begin{array}{l}\text { Aspek Kualitas } \\
\text { Teknis }\end{array}$ & 12 & 12 & 14 & 38 & 48 & 79 & Valid \\
\hline Jumlah & $\mathbf{6 0}$ & $\mathbf{5 7}$ & $\mathbf{6 6}$ & $\mathbf{1 8 3}$ & $\mathbf{2 2 8}$ & $\mathbf{8 0}$ & Valid \\
\hline
\end{tabular}

Kevalidan suatu instrumen atau produk dilihat berdasarkan 3 aspek yaitu aspek kualitas isi, aspek kualitas instruksional dan aspek kualitas teknis (Arsyad, 2011). Ditinjau dari aspek kualitas isi, vlog berbasis STEM dinyatakan valid dengan persentase $77 \%$. Dilihat dari segi aspek kualitas instruksional, vlog berbasis STEM dinyatakan sangat valid dengan persentase $85 \%$. Selain itu, dilihat dari segi kualitas teknis Dengan memperoleh presentase $79 \%$ dengan kriteria valid. Hasil persentase rata-rata yang dihasilkan ketiganya menunjukan nilai $80 \%$, maka media pembelajaran vlog (video blog) channel youtube berbasis STEM dinyatakan layak dan dapat digunakan dalam proses belajar mengajar.

Hasil praktikalitas produk dapat dilihat pada Tabel.5 sebagai berikut:

Table. 5 Hasil Praktikalitas Media Pembelajaran Vlog (Video Blog) Channel Youtube berbasis STEM

\begin{tabular}{|l|l|c|l|}
\hline No & \multicolumn{1}{|c|}{ Pernyataan } & $\%$ & \multicolumn{1}{|c|}{ Ket } \\
\hline 1. & $\begin{array}{l}\text { Gambaran isi setiap bagian media } \\
\text { pembelajaran vlog berbasis STEM } \\
\text { dinyatakan secara jelas }\end{array}$ & 97,5 & $\begin{array}{l}\text { Sangat } \\
\text { Praktis }\end{array}$ \\
\hline 2. & $\begin{array}{l}\text { Materi yang dimuat dalam media } \\
\text { pembelajaran vlog berbasis STEM } \\
\text { sesuai dengan Kompetansi Dasar (KD) } \\
\text { dan Tujuan Pembelajaran yang harus } \\
\text { dicapai }\end{array}$ & 97,5 & $\begin{array}{l}\text { Sangat } \\
\text { Praktis }\end{array}$ \\
\hline 3. & $\begin{array}{l}\text { Materi dalam media pembelajaran vlog } \\
\text { berbasis STEM ini disajikan secara urut }\end{array}$ & 97,5 & $\begin{array}{l}\text { Sangat } \\
\text { Praktis }\end{array}$ \\
\hline 4. & $\begin{array}{l}\text { Penjelasan materi pada setiap uraian } \\
\text { materi dapat dipahami }\end{array}$ & 95 & $\begin{array}{l}\text { Sangat } \\
\text { Praktis }\end{array}$ \\
\hline 5. & $\begin{array}{l}\text { Dengan mempelajari contoh soal, saya } \\
\text { mudah menyelesaikan masalah yang } \\
\text { berkaitan dengan materi dalam media } \\
\text { pembelajaran vlog berbasis STEM }\end{array}$ & 87,5 & $\begin{array}{l}\text { Sangat } \\
\text { Praktis }\end{array}$ \\
\hline 6. & $\begin{array}{l}\text { Setelah menggunakan media } \\
\text { pembelajaran vlog berbasis STEM saya } \\
\text { merasakan manfaat materi yang } \\
\text { diajarkan dalam kehidupan sehari-hari. }\end{array}$ & 95 & $\begin{array}{l}\text { Sangat } \\
\text { Praktis }\end{array}$ \\
\hline
\end{tabular}




\begin{tabular}{|c|c|c|c|}
\hline 7. & $\begin{array}{l}\text { Bahasa yang digunakan dalam media } \\
\text { pembelajaran vlog berbasis STEM } \\
\text { mudah dipahami. }\end{array}$ & 95 & $\begin{array}{l}\text { Sangat } \\
\text { Praktis }\end{array}$ \\
\hline 8. & $\begin{array}{l}\text { Media pembelajaran vlog berbasis } \\
\text { STEM mudah dan simple untuk } \\
\text { dipelajari }\end{array}$ & 100 & $\begin{array}{l}\text { Sangat } \\
\text { Praktis }\end{array}$ \\
\hline 9. & $\begin{array}{l}\text { Ukuran huruf yang digunakan dalam } \\
\text { media pembelajaran vlog berbasis } \\
\text { STEM cukup jelas dibaca. }\end{array}$ & 97,5 & $\begin{array}{l}\text { Sangat } \\
\text { Praktis }\end{array}$ \\
\hline 10. & $\begin{array}{l}\text { Letak gambar dan animasi dalam media } \\
\text { pembelajaran vlog berbasis STEM } \\
\text { sesuai dan mudah diamati. }\end{array}$ & 95 & $\begin{array}{l}\text { Sangat } \\
\text { Praktis }\end{array}$ \\
\hline 11. & $\begin{array}{l}\text { Gambar dan animasi yang disajikan } \\
\text { media pembelajaran vlog berbasis } \\
\text { STEM menarik dan mudah dimengerti. }\end{array}$ & 100 & $\begin{array}{l}\text { Sangat } \\
\text { Praktis }\end{array}$ \\
\hline \multicolumn{2}{|r|}{ Jumlah } & \multicolumn{2}{|r|}{423} \\
\hline \multicolumn{2}{|r|}{ Skor Maks } & \multicolumn{2}{|r|}{440} \\
\hline \multirow{2}{*}{\multicolumn{2}{|c|}{$\begin{array}{c}\% \\
\text { Keterangan }\end{array}$}} & \multicolumn{2}{|r|}{96,13} \\
\hline & & \multicolumn{2}{|c|}{ Sangat Praktis } \\
\hline
\end{tabular}

Berdasarkan hasil dari angket respon siswa yang telah divalidasi yang disebarkan kepada siswa kelas XI MIA didapatkan hasil bahwa vlog berbasis STEM pada materi laju reaksi dengan persentase 96,13\% dengan kriteria sangat praktis. Dimana dalam proses uji coba ini peneliti melakukan uji coba terbatas yang hanya dilakukan oleh 10 orang siswa. Media vlog berbasis STEM, apabila di lihat dari segi waktu penggunaan sangat efektif dan efisien dimana vlog berbasis STEM ini disajikan dengan waktu lumayan singkat sehingga dapat membantu keterbatasan waktu dalam proses pembelajaran, dan efisien untuk digunakan. Adapun dari segi kemudahan dalam penggunaan, vlog berbasis STEM ini sangat praktis untuk digunakan. Dikarenakan vlog berbasis STEM ini dapat di akses di youtube dan dapat ditonton secara online ataupun offline yang tersimpan didalam smartphone yang bisa dipelajari dimanapun dan kapanpun. Berdasarkan uraian diatas vlog berbasis STEM baik yang penulis lakukan maupun vlog berbasis STEM yang dilakukan oleh Muhammad lqbal dkk, dapat disimpulkan bahwa video blog channel youtube dengan pendekatan STEM layak dan praktis digunakan sebagai media alternatif pembelajaran daring untuk siswa sekolah SMA. Hal ini karena diantara kedua penelitian ini sama-sama memiliki rentang nilai kevalidan serta praktikalitas yang berkisar antara 80-100\% 


\section{Kesimpulan}

Kesimpulan dari penelitian adalah Vlog berbasis STEM ini memperoleh hasil validasi dengan persentase $80 \%$ dengan kriteria valid. Selanjutnya pada tahap praktikalitas dimana vlog berbasis STEM, diuji cobakan melalui angket respon siswa pada 10 orang siswa yang didapatkan persentase 96,13\% dengan kriteria sangat praktis sedangkan dari angket respon guru diperoleh persentase $90 \%$ dengan kriteria sangat praktis.

\section{Daftar Referensi}

Arsyad, A. (2011). Media Pembelajaran. Jakarta: PT RajaGrafindo Persada.

Mawaddah, N., Suhery, T., \& Wancik, K. A. (2017). Pengembangan Modul Pembelajaran Kimia Kelas X Pada Materi Reaksi Redoks Dengan Pendekatan STEM Problem Based Learning Di SMA Negeri 1 Indralaya Utara.

Prosiding Seminar Nasional Pendidikan IPA, 297-302.

Sugiyono. (2013). Metode Penelitian Kuantitatif Kualitatif Dan R\&D. Bandung: Alfabeta.

Triastuti, E. (2019). Pembelajaran berbasis STEM pada materi sel volta untuk meningkatkan keterampilan berfikir kreatif siswa. Jurnal Adikarsa , 15 (16), 3344.

Susilanan, R. dan Riyana, C. (2009). Media Pembelajaran. Bandung: CV Wacana Prima

Suratun, Irwandani, \& Latifah, S. (2018). Video pembelajaran berbasis problem solving terintegrasi chanel youtube : pengembangan pada materi cahaya kelas VIII SMP. Indonesian Journal of Science and Mathematics Education , 01 (3), 271282. 